\title{
Blood cells and alcohol consumption with special reference to smoking habits
}

\author{
E. ESCHWEGE 1 , L. PAPOZ, J. LellouCh, J. R. Claude, J. Cubeau, \\ G. PEQUIGNOT, J. L. RICHARD, AND D. SCHWARTZ
}

From the Groupe d'Étude sur l'Epidémiologie de l'Athérosclérose ${ }^{2}$ (GREA), 27 rue Lacordaire, 75015 Paris and INSERM, Division Médico-Sociale, Section Nutrition, 44 Chemin de Ronde, 78110 le Vesinet, France

SUMMARY In the course of the Paris study on risk factors of cardiovascular disease in a large professional group, 7710 active and apparently healthy men aged between 48 and 54 were examineds This study measured the relationship between clinical abnormalities suggesting alcoholic liver disease (ALD) and the following blood parameters: white (WBC) and red (RBC) blood cell counts, haema응 tocrit $(\mathrm{H})$, and mean corpuscular volume $(\mathrm{MCV})$, the former computed as $\mathrm{H} / \mathrm{RBC}$ ratio. A sub-sequent analysis was performed on a random sample of 485 subjects without ALD who were questioned on their daily average alcohol consumption. Each subject was classified as 'smoker' of 'non-smoker' according to his daily tobacco consumption for the last five years. Analysis of the dati\$ㅇำ confirmed that smoking and alcohol were related to the blood parameters; but, according to smoking habit, different relationships between alcohol consumption (or ALD) and MCV, RBC, or WBC counts were found: for smokers, RBC count significantly decreased and MCV increased witt alcohol consumption (or ALD); for non-smokers, WBC count significantly increased with alcohof consumption (or ALD). So, it would be of interest to consider the relation between alcohol an $\frac{8}{8}$ tobacco in interpreting possible changes in blood parameters and in formulating hypotheses on the mechanisms of their specific action.

Recent papers have shown a relationship between alcohol consumption and mean corpuscular volume (MCV) in patients free of chronic liver disease or liver cirrhosis (Buffet et al., 1975; Wu et al., 1974; Wu et al., 1975; Morin and Porte, 1976). Also epidemiological studies have shown that the white blood cell count (Howell, 1970; Corre et al., 1971; Friedman et al., 1973; Okuno, 1973), haematocrit, and MCV increased with smoking (Lambert and Morris, 1971; Okuno, 1973). Because of the wellknown strong association between alcohol and smoking, it was of interest to consider tobacco consumption in order to study the influence of alcohol on blood cells, especially in healthy subjects.

'INSERM, Unité de Recherches Statistiques, 16 bis avenue Paul Vaillant Couturier, 94800 Villejuif, France. ${ }^{2}$ With the assistance of the Prefecture de Paris (Direction Générale de l'Action Sanitaire et Sociale, Service de Dépistage Systématique de la Tuberculose et des Affections Cardio-vasculaires), and of INSERM (Division de la Recherche Medico-Sociale, Section de Cardiologie; Unité de Recherches Statistiques et Centre National de Calcul), and the help of the Ministère de la Santé.

Received for publication 21 November 1977

\section{Material and methods}

The present enquiry was made within the framewor of the prospective study on cardiovascular ris $\bar{B}$. factors carried out in Paris by the Groupe d'Etudi sur l'Epidémiologie de l'Athérosclérose (GREA (Ducimetière et al., 1973) concerning 7710 activelø employed and apparently healthy men aged between 48 and 54 from a large professional group.

The routine examination included: (1) Screenin for clinical abnormalities: volume and consistenco of the liver suggestive or not of alcoholic liver disease (ALD); (2) A fasting venous blood sample taken from the antecubital vein into an EDTA tube From this sample white and red cell (WBC and RBC) counts were measured by Fisher's auto cytometer. Haematocrit $(H)$ was measured and the MCV was calculated as the ratio H/RBC. (3) questionnaire on smoking habits: the subjects wer $\bar{E}$ divided into 'non-smokers' and 'smokers', depending on whether their mean daily consumption of tobacco in the last five years had been less or more than $1 \mathrm{~g}^{1}$.

${ }^{1} 1$ cigarette $=1 \mathrm{~g}, 1$ pipe $=2 \mathrm{~g}, 1$ cigar $=4 \mathrm{~g}$ 
Table 1 Blood parameter means ( \pm SEM) according to clinical signs of alcoholic liver disease in 7710 subjects

\begin{tabular}{|c|c|c|c|c|c|}
\hline$A L D$ & $\begin{array}{l}\text { Total population } \\
I\end{array}$ & $\begin{array}{l}\text { Non-smokers } \\
2\end{array}$ & $\underset{3}{\text { Smokers }}$ & $\begin{array}{l}d \\
(3-2)\end{array}$ & $\begin{array}{l}\text { Comparison } \\
\text { smokers/non-smokers }\end{array}$ \\
\hline \multicolumn{6}{|l|}{$\mathrm{WBC} / \mathrm{mm}^{\mathrm{s}}$} \\
\hline No & $6403 \pm 23$ & $\begin{array}{l}5720 \pm 33 \\
(1952)^{*}\end{array}$ & $\begin{array}{l}6654 \pm 28 \\
(5317)\end{array}$ & 934 & $P<10^{-\theta}$ \\
\hline Yes & $6750 \pm 97$ & $\begin{array}{l}6332 \pm 224 \\
(71)\end{array}$ & $\begin{array}{l}6830 \pm 107 \\
(370)\end{array}$ & 498 & $P<0.05$ \\
\hline Difference & 341 & 612 & 176 & & \\
\hline $\mathbf{P}$ & $P<10^{-3}$ & $P<10^{-2}$ & NS & & $\mathrm{I} \dagger: \mathrm{P}<0.05$ \\
\hline \multicolumn{6}{|l|}{$\mathrm{RBC} / \mathrm{mm}^{3}$} \\
\hline No & $4672 \pm 4$ & $\begin{array}{l}4695 \pm 8 \\
(1950)\end{array}$ & $\begin{array}{l}4663 \pm 5 \\
(5316)\end{array}$ & -32 & $P<10^{-3}$ \\
\hline Yes & $4532 \pm 21$ & $\begin{array}{l}4691 \pm 48 \\
(71)\end{array}$ & $\begin{array}{l}4502 \pm 23 \\
(369)\end{array}$ & -189 & $P<10^{-3}$ \\
\hline Difference & -140 & -4 & -161 & & \\
\hline & $P<10^{-0}$ & NS & $P<10^{-9}$ & & $\mathrm{I}: \mathrm{P}<0.05$ \\
\hline \multicolumn{6}{|l|}{ Haematocrit } \\
\hline No & $45.0 \pm 0.03$ & $\begin{array}{l}44.7 \pm 0.06 \\
(1945)\end{array}$ & $\begin{array}{l}45 \cdot 2 \pm 0 \cdot 04 \\
(5306)\end{array}$ & 0.5 & $P<10^{-9}$ \\
\hline Yes & $45 \cdot 0 \pm 0 \cdot 16$ & $\begin{array}{l}45 \cdot 2 \pm 0 \cdot 35 \\
(71)\end{array}$ & $\begin{array}{l}45 \cdot 0 \pm 0.18 \\
(367)\end{array}$ & -0.2 & NS \\
\hline Difference & 0 & 0.5 & 0.2 & & \\
\hline \multirow{2}{*}{\multicolumn{6}{|c|}{$\mathrm{MCV} / \mu^{3}$}} \\
\hline & & & & & \\
\hline No & $96.6 \pm 0.06$ & $\begin{array}{l}95 \cdot 3 \pm 0 \cdot 10 \\
(1943)\end{array}$ & $\begin{array}{l}97 \cdot 1 \pm 0.07 \\
(5304)\end{array}$ & $1 \cdot 8$ & $P<10^{-8}$ \\
\hline Yes, & $99 \cdot 7 \pm 0.31$ & $\begin{array}{l}96 \cdot 6 \pm 0.60 \\
(71)\end{array}$ & $\begin{array}{l}100 \cdot 3 \\
(366)\end{array}$ & $3 \cdot 7$ & $\mathbf{P}<10^{-7}$ \\
\hline Difference & $3 \cdot 1$ & 1.3 & $3 \cdot 2$ & & \\
\hline $\mathbf{P}$ & $P<10^{-9}$ & $P<0.05$ & $P<10^{-9}$ & & $\mathrm{I}: \mathrm{P}<0.05$ \\
\hline
\end{tabular}

*Number of subjects in parentheses

$\dagger \mathrm{I}=$ interaction

In addition, of these 7710 subjects a random sample of 485 men without ALD attending between October 1969 and December 1970 were questioned on their dietary habits (Papoz et al., 1974). The techniques used provided, in particular, the mean daily alcohol consumption expressed in grams of pure alcohol ${ }^{1}$ assessed from the quantities of the various drinks taken in the course of the week and their respective alcohol content.

\section{Results}

BLOOD CELLS, ALCOHOLIC LIVER DISEASE, AND SMOKING HABIT (Table 1)

Signs of definite or possible alcoholic liver disease were found in $6 \%$ of the 7710 subjects in the study. It can be seen (first column of Table 1) that the RBC count was significantly lower and the WBC count and MCV higher for subjects with ALD than for those without.

When smoking habits were taken into account in a two-way analysis of variance, a significant interaction between ALD and smoking was seen.

On the one hand, the differences between subjects with and without ALD varied according to smoking habit:

11 litre of $10^{\circ}$ wine contains $80 \mathrm{~g}$ of pure alcohol.
Among smokers, there was no significant difference in the WBC count, but the RBC count was significantly lower in subjects with ALD than in subjects without ALD.

Among non-smokers, there was no significant difference in the RBC count, but the WBC count was significantly higher when subjects showed signs of ALD.

MCV was significantly higher in men with ALD whatever their smoking habits, but the difference was much greater in smokers than in non-smokers (3.2 $v 1.3 \mu^{3}$, Table 1).

On the other hand, the comparison between smokers and non-smokers shows that the influence of tobacco differed according to the presence or absence of clinical signs of ALD: thus, the difference in WBC counts barely reached the $5 \%$ level of significance $(P=0.03)$ and the haematocrits did not differ significantly between smokers and nonsmokers who had clinical signs of ALD, but the values were significantly higher in the group of smokers without signs of ALD. The RBC counts were significantly lower in smokers than in nonsmokers, independent of the presence or absence of clinical signs of ALD but the difference was more evident in subjects with ALD $\left(32 / \mathrm{mm}^{3} \times 10^{3}\right.$ without ALD and $189 / \mathrm{mm}^{3} \times 10^{3}$ with ALD); for the MCV there was a similar otservation: the 
mean differences in MCV between smokers and non-smokers respectively were 3.7 and $1.8 \mu^{3}$, depending on whether they did or did not have clinical signs of ALD.

BLOOD CELLS, SMOKING HABITS, AND ALCOHOL CONSUMPTION (Table 2)

This second analysis was undertaken on the random sample of 485 subjects to confirm, by estimating their alcohol consumption, the results obtained from the clinical observation of ALD on the whole population.

For this sample a one-way analysis of variance of the blood parameter means in groups of men with increasing amounts of ingested alcohol and a comparison of correlation coefficients showed a significant decrease in the $\mathrm{RBC}$ count and a significant increase in the MCV. Haematocrit did not vary significantly, and the WBC count increased but barely reached the $5 \%$ level of significance fo the correlation coefficient (first column of Table 2). 을

The specific role of alcohol was studied by once again separating smokers from non-smokers anff adjusting for the amount smoked. Significant relationships between the quantity of alcohos: ingested and either the $\mathrm{WBC}$ or the $\mathrm{RBC}$ counte or the MCV appeared in non-smokers only for $\mathrm{WBC}$, and in smokers for RBC and MCV alsos The interaction computed from a two-way analysis of variance did not reach the $5 \%$ level of significance except for the RBC count. A comparison of the correlation coefficients showed no significant differ ences although for WBC and RBC counts the actua significance levels were respectively $P=0.0 \%$ $P=0.06$, and $P=0.14$ for MCV. The specific role of smoking could not be studied in the same ways since too few subjects were total abstainers.

It could, however, be noted that the association

Table 2 Changes in blood parameters according to amount of alcohol ingested and smoking habit in random sample $\overparen{\oplus}$ of 485 subjects (mean $\pm S E M)$

\begin{tabular}{|c|c|c|c|c|c|}
\hline Alcohol (g/day) & $\begin{array}{l}\text { Total population } \\
1\end{array}$ & $\begin{array}{l}\text { Non-smokers } \\
2\end{array}$ & $\begin{array}{l}\text { Smokers } \\
3\end{array}$ & $\begin{array}{l}d \\
(3-2)\end{array}$ & $\begin{array}{l}\text { Comparison } \\
\text { smokers/non-smokers }\end{array}$ \\
\hline \multicolumn{6}{|l|}{$\mathrm{WBC} / \mathrm{mm}^{3}$} \\
\hline$<40$ & $6382 \pm 107$ & $\begin{array}{l}5823 \pm 153 \\
(75)^{*}\end{array}$ & $\begin{array}{l}6705 \pm 136 \\
(128)\end{array}$ & 882 & $P<10^{-4}$ \\
\hline $40-59$ & $6641 \pm 155$ & $\begin{array}{l}5841 \pm 189 \\
(32)\end{array}$ & $\begin{array}{l}6900 \pm 189 \\
(99)\end{array}$ & 1059 & $P<10^{-4}$ \\
\hline $60-79$ & $6724 \pm 190$ & $\begin{array}{l}6473 \pm 357 \\
(11)\end{array}$ & $\begin{array}{l}6766 \pm 214 \\
(67)\end{array}$ & 293 & 一 \\
\hline$\geqslant 80$ & $6834 \pm 213$ & $\begin{array}{l}6617 \pm 414 \\
(18)\end{array}$ & $\begin{array}{l}6938 \pm 251 \\
(55)\end{array}$ & 321 & 一 \\
\hline $\begin{array}{l}\text { Significance (analysis of } \\
\text { variance) }\end{array}$ & - & - & 一 & & Interaction NS \\
\hline ' $r$ ' correlation & 0.09 & $0 \cdot 20$ & 0.03 & & NS \\
\hline coefficient & $P<0.05$ & $P<0.05$ & 一 & & $P<0.07$ \\
\hline \multicolumn{6}{|l|}{$10^{3} \mathrm{RBC} / \mathrm{mm}^{3}$} \\
\hline$<40$ & $4717 \pm 24$ & $4618 \pm 35$ & $4725 \div 31$ & 107 & $P<0.02$ \\
\hline $40-59$ & $4656 \pm 28$ & $4716 \pm 54$ & $4637 \pm 33$ & -79 & - \\
\hline $60-79$ & $4635 \pm 34$ & $4882 \pm 108$ & $4594 \pm 33$ & -288 & $P<0.01$ \\
\hline$\geqslant 80$ & $4568 \pm 42$ & $4678 \pm 88$ & $4535 \pm 48$ & -143 & 一 \\
\hline $\begin{array}{l}\text { Significance (analysis of } \\
\text { variance) }\end{array}$ & $P<0.01$ & - & $P<0.01$ & & Interaction $\mathbf{P}<0.05$ \\
\hline ' $r$ ' correlation & $-0 \cdot 18$ & 0.03 & $-0 \cdot 22$ & & NS \\
\hline coefficient & $P<10^{-4}$ & 一 & $P<10^{-4}$ & & $P<0.06$ \\
\hline \multicolumn{6}{|l|}{ Haematocrit } \\
\hline $\begin{array}{l}<40 \\
40-59\end{array}$ & $45 \cdot 0 \pm 0 \cdot 2$ & $44.5 \pm 0.3$ & $45 \cdot 2 \pm 0 \cdot 2$ & 0.7 & NS \\
\hline $40-59$ & $45 \cdot 0 \pm 0.2$ & $44 \cdot 5 \pm 0.4$ & $45 \cdot 2 \pm 0 \cdot 2$ & 0.7 & NS \\
\hline $60-79$ & $45 \cdot 1 \pm 0 \cdot 3$ & $46.4 \pm 0.9$ & $44.9 \pm 0.9$ & $-1 \cdot 5$ & NS \\
\hline$\geqslant 80$ & $44.9 \pm 0.3$ & $44.9 \pm 0.6$ & $45.0+0.4$ & $0 \cdot 1$ & NS \\
\hline $\begin{array}{l}\text { Significance (analysis of } \\
\text { variance) }\end{array}$ & - & - & 一 & & Interaction NS \\
\hline $\begin{array}{l}\text { ' } r \text { ' correlation } \\
\text { coefficient } \\
\mathrm{MCV} / \mu^{3}\end{array}$ & -0.02 & 0.04 & 0.05 & & NS \\
\hline \multicolumn{6}{|l|}{$\mathrm{MCV} / \mu^{3}$} \\
\hline $\begin{array}{l}<40 \\
40-59\end{array}$ & $\begin{array}{l}95 \cdot 5 \pm 0.3 \\
97 \cdot 0 \pm 0.4\end{array}$ & $94.8 \pm 0.5$ & $95.9 \pm 0.4$ & $1 \cdot 1$ & NS \\
\hline $40-59$ & $97.0 \pm 0.4$ & $94.6 \pm 0.6$ & $97.8 \pm 0.6$ & $3 \cdot 2$ & $P<0.001$ \\
\hline $60-79$ & $97 \cdot 5 \pm 0.5$ & $95 \cdot 1 \pm 1 \cdot 0$ & $97 \cdot 9 \pm 0.5$ & $2 \cdot 8$ & $P<0.02$ \\
\hline$\geqslant 80$ & $98.7 \pm 0.7$ & $96.2 \pm 0.9$ & $99 \cdot 5 \pm 0.9$ & $3 \cdot 3$ & $P<0.02$ \\
\hline $\begin{array}{l}\text { Significance (analysis of } \\
\text { variance) }\end{array}$ & $\mathbf{P}<10^{-4}$ & 一 & $P<10^{-3}$ & & Interaction NS \\
\hline ' $r$ ' correlation & $0 \cdot 23$ & $0 \cdot 10$ & $0 \cdot 35$ & & NS \\
\hline coefficient & $P<10^{-*}$ & & $\mathbf{P}<10^{-5}$ & & $P<0.14$ \\
\hline
\end{tabular}

*Number of subjects in parentheses 
between smoking habit and blood parameters was not always the same according to the amount of alcohol ingested, especially for the WBC count. Significant differences between smokers and nonsmokers were observed only for alcohol consumption below $60 \mathrm{~g} /$ day, and smokers had higher RBC counts for an alcohol consumption below $40 \mathrm{~g} /$ day and lower RBC counts for an alcohol consumption over $60 \mathrm{~g} /$ day.

\section{Discussion}

The results obtained in the present study support some findings already described by other authors, especially the relationship between $\mathrm{MCV}$ and chronic alcoholism or alcohol ingestion.

With regard to the relationship between chronic alcoholism and blood cells, many studies have been carried out on patients suffering from cirrhosis or chronic liver disease. They have revealed the presence of erythrocytic macrocytosis with or without anaemia and no change in haematocrit (Bianco and Joliffe, 1938; Herbert et al., 1963; Kumar et al., 1966; Boivin, 1968; Boivin and Fauvert, 1969; Buffet et. al. 1975; Morin and Porte, 1976).

With regard to the relationship between alcohol consumption and changes in blood parameters, there seem so far to be only two studies on healthy subjects (Unger and Johnson, 1974; Wu et al., 1974) that have dealt with this. One, by Wu et al. (1974), compares 63 subjects with no detected liver disease, drinking more than $80 \mathrm{~g}$ of alcohol daily, with 61 healthy subjects, members of the medical staff. It shows, in the first group, an increased MCV without anaemia and no change in haematocrit. The other, by Unger and Johnson (1974), shows that among 77 subjects, employees of an insurance company systematically selected for their increased MCV, 27 were heavy or very heavy drinkers.

Our study gives additional information on the relationship between alcohol consumption and counts of both white and red blood cells, and especially on the separate roles of smoking and alcohol that no other study seems to have investigated simultaneously so far. Associated with an increased MCV was a fall in the RBC count, though not to the extent of anaemia, the product of these two variables-haematocrit-being constant. However, the correlation of alcohol consumption with the RBC count and MCV was more marked in smokers; on the other hand, its correlation with the WBC count was more marked in non-smokers.

From the pathological point of view, the mechanism by which chronic alcoholism acts on the blood parameters is not known. Without excluding that concomitant parameters related to drinking and smoking (ie, dietary habits) are major factors, it seems reasonable to assume that alcohol has a direct toxic effect independent of hepatic disease (Wu et al., 1974; Buffet et al., 1975). As to the interactions mentioned above, it is difficult to find an explanation: for the WBC changes it is possible only to suggest that the effect of tobacco is so strong (Corre et al., 1971; Friedman et al., 1973) that, among smokers, the relation to alcohol cannot be determined.

In conclusion, this study, carried out on 7710 active and healthy subjects who submitted to systematic clinical examination and questioning as to their smoking habits and, for nearly 500 of them, their alcohol consumption, confirms that smoking and alcohol may affect the blood parameters. It emphasises the need to consider the relation between two products currently consumed, alcohol and tobacco, when (1) formulating hypotheses on the mechanism of their specific action and their possible interaction; and (2) interpreting possible changes in blood parameters, whether as a criterion for the early diagnosis of alcoholism or as a reference for alcohol withdrawal (Buffet et al., 1975; Morin and Porte, 1976).

This study was supported by grant ATP.FA/57 from the Institut National de la Santé de la Recherche Médicale, Paris. We thank Mrs Fenelon for her invaluable technical assistance.

\section{References}

Bianco, A., and Joliffe, N. (1938). The anemia of alcoholics addicts. Observations as to the role of liver disease, achlorhydria, nutritional factors and alcohol on its production. American Journal of Medical Sciences, 196, 414-420.

Boivin, P. (1968). Quelques aspects de la biologie du foie alcoolique en dehors de la cirrhose. Revue Internationale d'Hépatologie, 18, 243-264.

Boivin, P., and Fauvert, R. (1969). Les anémies des cirrhoses. Revue critique. Pathologie et Biologie, 17, 645-655.

Buffet, C., Chaput, J. C., Albuisson, F., Subtil, E., and Etienne, J. P. (1975). La macrocytose dans l'hepatite alcoolique chronique histologiquement prouvée. Archives Françaises des Maladies de l'Appareil Digestif, 64, 309-315.

Corre, F., Lellouch, J., and Schwartz, D. (1971). Smoking and leucocyte-counts. Results of an epidemiological survey. Lancet, 2, 632-634.

Ducimetière, P., Bonnaud, G., Claude, J. R., Corre, F., Elgrishi, I., Eschwege, E., Gélin, J., Lellouch, J., Richard, J. L., Schwartz, D., and Warnet, J. M. (1973). Facteurs de risque des cardiopathies ischémiques. Premiers résultats de l'étude prospective parisienne. Colloques de l'INSERM, 21, 115-138. 
Friedman, G. D., Siegelaub, A. B., Seltzer, C. C., Feldman, R., and Collen, M. F. (1973). Smoking habits and the leukocyte count. Archives of Environmental Health, 26, 137-143.

Helman, N. (1974). Leukocyte count in smokers. (Letter). New England Journal of Medicine, 291, 630.

Herbert, V., Zalusky, R., and Davidson, C. S. (1963). Correlation of folate deficiency with alcoholism and associated macrocytosis, anemia, and liver disease. Annals of Internal Medicine, 58, 977-988.

Howell, R. W. (1970). Smoking habits and laboratory tests (Letter). Lancet, 2, 152.

Kumar, S., Dube, B., and Mehrotra, P. N. (1966). The macrocytosis in cirrhosis of the liver. A clinical and experimental study. Acta Haematologica, 35, 30-45.

Lambert, R. J. W., and Morris, J. E. W. (1971). Red cell size and air composition (Letter). British Medical Journal, 3, 706.

Morin, J., and Porte, P. (1976). Macrocytose érythrocytaire chez les éthyliques. La nouvelle Presse Médicale, $5,273$.

Okuno, T. (1973). Smoking and blood changes. (Letter). Journal of the American Medical Association, 225, 1387-1388.
Papoz, L., Cubeau, J., Eschwege, E., and Pequignot, (1974). Exploitation par ordinateur des enquêtes. alimentaires quantitatives. Programme général d'ana $z^{\circ}$ lyse nutritionnelle. Annals de la Nutrition et de l'Alts? mentation, 28, 465-485.

Unger, K. W., and Johnson, D. Jr. (1974). Red bloo cell mean corpuscular volume: a potential indicator of alcohol usage in a working population. America別 Journal of Medical Sciences, 267, 281-289.

Wu, A., Chanarin, I., and Levi, A. J. (1974). Macroळ cytosis of chronic alcoholism. Lancet, 1, 829-831.

Wu, A., Chanarin, I., Slavin, G., and Levi, A. J. (1975):Folate deficiency in the alcoholic-its relationship ta clinical and haematological abnormalities, live? disease and folate stores. British Journal of Haemas tology, 29, 469-478.

Requests for reprints to: Professor D.Schwartz, Director? Unité de Recherches Statistiques, Institut National de lâa Santé et de la Recherche Médicale, 16 bis Avenuê Paul-Vaillant-Courturier, 94800 Villejuif, France. 